\title{
STUDENTS' READING PREFERENCE AND ITS IMPLICATIONS: A STUDY OF THREE ENGLISH EDUCATION DEPARTMENTS IN JEMBER
}

\author{
Sari Dewi Noviyanti \\ State Islamic Institute of Jember \\ e-mail: sari.dewinoviyanti@gmail.com
}

\begin{abstract}
This study aims to determine the students' reading preference and its implications of three English Education Departments in Jember. Getting learners' full attention in the learning process is very important, because the ability to read is one element of language competences that always needs to be elevated. However, reading material usually becomes the biggest obstacle for the lecturer to engage students' full interest to the course. This study involved 273 students of three English Education Departments in Jember as research objects. Survey and interview methods were used to obtain the data. The research findings show that English Education Department students mostly interested to reading materials about entertainment and lifestyle, arts, religious, education and historical theme, and they avoid reading political and sport. Based on these findings, the suggestion for lecturers who specialize in the subjects related to reading activities is they should be able to present the teaching materials with themes favored by students in order to improve students' reading motivation.
\end{abstract}

Keywords : reading, motivation, preference

\section{INTRODUCTION}

Learning English in class should be conducted effectively and fun. Effective in the sense that learning goals can be achieved, and fun in the sense that students can follow the learning without pressure and in accordance with their interests. Creating fun learning will make students focus their attention fully on learning so that the time on task is high. According to the results of research conducted by Nurseto (2011), the high time of attention was proven to improve learning outcomes. According to Suprijono (2009), fun learning is a learning with positive emotional climate learning. Learners feel that the learning process they experience is not a pain that beats them, but a blessing that must be measured. Learning is not the pressure of the soul on him, but is a call of the soul that must be fulfilled. That's why it's important to create a fun learning atmosphere, one of which is to expose students to the material they like so that they can create interesting learning. By using fun teaching materials, it will make students feel interested and enjoy learning the teaching material.

Meanwhile, of the four language competencies, reading competence is known as one of the most important aspects of any language and is an important tool for lifelong learning for students. Having good reading skills can help people unlock new knowledge, explore new ideas and provide new opportunities. Even a study conducted by McKendery and Murphy (2011) said that reading activities are the key to the development of a nation. But in reality, Based on the "Most Littered Nation In the World" study conducted by Central Connecticut State University in March 2016, Indonesia was declared 60th out of 61 countries based on our reading interest. According to UNESCO, interest in reading in Indonesia is only $0.001 \%$. This means that from every 1000 people there is only 1 person who has a reading interest. Based on those findings, it becomes an important thing for Indonesia to increase reading interest of students to support national reading development.

Reading is a dynamic process and actively engages readers to improve vocabulary and information. As a process of communication between the writer and the reader, reading activities are an attempt by the reader to understand the message of the author

Reading is done by someone for various reasons. There are those who use reading 
activities for pleasure, to extract information and the most common is reading as a significant process in one's academic life that leads to knowledge. Reading can guide individuals to develop creativity and critical thinking

To provide an encouragement and motivation so that students like to do reading activities are very important to pay attention to students' interests or reading preferences. Interest in certain topics or subjects can motivate students to start "reading". So, it is very important to pay attention to the students' reading choices. An effort is needed to identify reading options, to make the material produced and given in class accessible to them and to make learning enjoyable.

With this background, it seems important to conduct basic studies to find out the reading attitudes and reading preferences of English Language Teaching students in Jember. Identifying students 'reading preferences can be used to explore students' interests so that they can improve their reading skills. The availability of reading material according to their interests is expected to make them interested in participating in learning so that the transformation of knowledge will be easier to do. So, it is expected that students will still be able to improve their reading skills but in pleasant situations because text material will suit their reading interests. This will also help all stakeholders, writers, publishers, parents and also the library, so that the relevant parties can provide better services to provide books and reading materials that are suitable for students' interests. More specifically, the present study attempts to answer the following questions: 1) what are the students' of English Language Teaching students in Jember attitude toward reading activities? 2) what are the reading preferences of English Language Teaching students in Jember.

There are several review of the literatures and previous studies showed how a reading preferences and interest really affects students' motivation and achievement on reading. Reading has been considered the most important language competence of the four language skills. Therefore, various aspects of reading have been widely researched in recent years. Some of Koch's studies (1974) on reading competence, the most productive aspects reported in the literature, have paid attention to readers' interests, preferences and tastes, because educators have realized the importance of reading interest as a driving factor in the reading process.
Reading is also considered an important skill by all types of people, and is considered important for the prospects of community work. Parents feel that reading with their children is very important and an important part of the development of their children. However, despite the universal belief in the importance of reading, various groups of people (including students) have different attitudes toward reading and have very different interests and reading habits.

Interest or preference according to Poerbakawatja (1981) is the willingness of an active soul to receive something from the outside. Interest is divided into two types, namely spontaneous interest and patterned interest. Spontaneous interest is an interest that grows spontaneously from within a person without being influenced by outsiders. Patterned interest is an interest that arises as a result of influence and planning or patterned activities, especially teaching and learning activities, both at school and outside of school.

Interest in reading according to Tampubolon (1993) is a strong and deep concern accompanied by a feeling of pleasure towards reading activities so that it can direct someone to read on their own accord. Reading interest is also interpreted as a positive attitude and a sense of self-attachment to reading activities and interested in reading books. Reading interest includes feeling happy about reading books, awareness of the benefits of reading, the number of reading books that have been read, and attention to reading books.

Reading habits are a form of patterned interest, where the habit is present due to a significant influence given to someone. As someone who plays a role in fostering reading activities among students, the task of educators is to provide motivation to encourage students' awareness in wanting to do reading activities.

Reading becomes fun when reading material has an attraction for students, so students will read it seriously which will further support students' reading comprehension. Readings can be taken from textbooks, literature books, magazines, newspapers and reference books. Allowing students to read according to their desires and interests motivating them to learn to read, having a more positive, and consequent attitude, preferring to do the best in reading. Some studies confirm that the choice of books must come from students rather than being forced by the teacher. Choosing books according to personal interests increases the level of motivation of students, 
encourages them to apply positive attitudes, and perform better

According to Santhy Subbarau and Marissa Bt. Abd. Mustafa (2013) revealed that reading has been a core of language learning skills and an essential tool for lifelong learning for centuries. Facts were found referring to reading and the selection of materials correlates in bringing the best in comprehending what has been read. In an absolute condition, it's to highlight on the selection of reading materials on what do students seek and preferred. Students want variety and look into many modes for aspiration as a guide and input for the language learning classroom.

Bataineh and Al-Barakat (2005) on their study investigated the students reading interests, their source of reading materials, and students' attitude toward reading. They found students' top preference are stories and picture books/magazines. They also found that the school library is their major source of reading materials. Further, the students were found to have a positive attitude towards reading. Moreover, lack of incentives and excessive school homework were perceived as the major obstacles hindering the pupils' literacy development.

Other research conducted by Khaled AlNafisah and Rae'd Abdulgader Al-Shorma (2011) which investigated the reading interests of Saudi EFL teacher-college found that the students actually have a wide range of reading interests and preferences. The top of which are stories, adventure books, books about religion, magazines about the internet, newspaper world events, magazines about computer, magazines about new advances in technology, sports magazines, newspaper local interests, newspaper sports sections, books about the internet, picture magazines, books about computers, novels, poetry, and plays. On the other hand, they are found to dislike books about economics. The findings also showed that the obstacles that hinder their reading efforts are unavailability of reading materials, lack of local libraries, and the difficulty of reading materials provided by English departments. Furthermore, the findings revealed that the student choose their reading materials by interest, teacher's request, the main character, length, literary quality, and cost.

Another research from Yamina Bouchamma, Vincent Poulin, Marc Basque, and Catherine Ruel (2013) investigated the reading preferences of 13-year-old boys and girls to identify the factors determining reading achievement. The research indicates that reading achievement for both sexes was determined by identical reading preferences: reading novels, informative texts, and books from the school library, as well as level of interest in the class reading material and participation in the discussions on what was read in class.

Based on those literatures above, reading interest becomes an important thing to be conidered to elevate students literacy activities. The reading interest itself not only comes from inside but also should be stimulated from outside simply from teachers and other facilities support like teaching materials, sumplementary books, teksbooks, etc. By concerning their reading interest, they will elevate their positive attitudes to the reading activitesin classroom.

\section{METHOD}

The present study is intended to answer two research questions, which are 1) what are the students' of English Language Teaching students in Jember attitude toward reading activities? 2) what are the reading preferences of English Language Teaching students in Jember?. This study is a qualitative design and uses a survey methodology. In order to find the result for this study, the data was analyzed quantitatively.

The instruments used in this study was A set of questionnaire are duly adapted from Arnstead (2004) Influences on Students' SelfSelected, Recreational Reading Material and Larsen (1999) A Study of the Reading Interests of High-Ability Readers in a North Carolina Elementary School are used in this study. The questionnaires were distributed to the respondents and analyzed quantitatively. The questions selected are relevant to the present study and exclude the irrelevant. We also added new constructed question based on the necessity in order to answer our research questions.

The participants of this research selected among the students of English Language Teaching from three different universities in Jember; State Islamic Institute of Jember, University of Jember and Muhammadiyah University of Jember. The participants selected are from all semester with various age between 19-22 years old, and their first language is ranging from Javanese, Maduranese and Bahasa Indonesia. 


\section{FINDINGS}

The first question is about reading activities done in class. This question refers to students' attitudes towards reading activities conducted in class whether they always like the reading activities, or not always like it. Responses are shown in Table 1.

Table 1. Attitudes towards Reading Activities in Classes

\begin{tabular}{cccc}
\hline No. & Sex & \multicolumn{2}{c}{ Answer } \\
\cline { 3 - 4 } $\mathbf{1}$ & & Yes & No \\
$\mathbf{2}$ & Male & 22 & 31 \\
& Female & 89 & 131 \\
& Sum & 111 & 162 \\
\hline
\end{tabular}

From the table above it was found that 162 students do not always like the reading activities in class, while 111 students always like their reading activities in class. The reasons given were varied, including difficult to concentrate, less conducive class atmosphere, too difficult reading material, unintersting topics and others.
The second question refers to the students' attitude towards the reading texts they get in class whether they always like the reading texts given by their lecturers or do not always like the texts. Responses are shown in Table 2.

Table 2. Attitudes toward Reading Text in Classes

\begin{tabular}{lccc}
\hline No. & Sex & \multicolumn{2}{c}{ Answer } \\
\cline { 3 - 4 } $\mathbf{1}$ & & Yes & No \\
\hline $\mathbf{2}$ & Male & 26 & 27 \\
& Female & 76 & 144 \\
& Sum & 102 & 171 \\
\hline
\end{tabular}

From the table above it was found that 171 students do not always like the reading texts provided by their lecturers and 102 students always like the reading texts provided by their lecturers. The reasons given include, among other things, the text does not suit students' interests, the text is too difficult, and others.
The question about reading frequency is related to how often students do reading activities both in the classroom and outside the classroom. This reading frequency is important to be asked to see how students tend to read in their daily lives, whether it is done frequently, sometimes or even rarely. Responses from students are available in table 3.

Table 3. Frequency of Reading

\begin{tabular}{ccccc}
\hline \multirow{2}{*}{ No. } & Sex & \multicolumn{3}{c}{ Answer } \\
\cline { 3 - 5 } & & Often & Seldom & Rarely \\
\hline $\mathbf{1}$ & Male & 8 & 40 & 5 \\
\hline $\mathbf{2}$ & Female & 44 & 155 & 21 \\
\hline & Sum & 52 & 195 & 26 \\
\hline
\end{tabular}

From the table above it can be seen that 52 students categorized as frequent reading, 195 students do the reading sometimes, and 26 students are rarely read
Student reading preferences in this study are based on questions about their collection of reading books, types of reading and preferred reading topics, the most preferred and least preferred reading topics. For the first question, 
respondents were given questions about their reading collection or what type of reading they have the most. Respondents' responses are available in table 4 .

Table 4. Reading Collection

\begin{tabular}{rccccccc}
\hline \multirow{2}{*}{ No. } & Sex & \multicolumn{7}{c}{ Answer } \\
\cline { 3 - 7 } & & Textbook & Literature & Comic & Magazine & Newspaper \\
\hline $\mathbf{1}$ & Male & 26 & 14 & 6 & 2 & 5 \\
\hline $\mathbf{2}$ & Female & 102 & 55 & 35 & 14 & 14 \\
\hline & Sum & 128 & 69 & 41 & 16 & 19 \\
\hline
\end{tabular}

From the table above, it can be seen that the majority of students, 128 of them have textbook for their book colllection, then followed by a literature book of 69 students, 41 students chose comics, 16 students chose newspapers, and 19 students chose magazines.

Table 5. Types of Reading

\begin{tabular}{cccc} 
No. & Sex & \multicolumn{2}{c}{ Answer } \\
\cline { 3 - 4 } & & Fiction & Non Fiction \\
\hline $\mathbf{1}$ & Male & 32 & 21 \\
\hline $\mathbf{2}$ & Female & 131 & 89 \\
\hline & Sum & 163 & 110 \\
\hline
\end{tabular}

From the table above, it can be seen that 163 students prefer fiction reading, and 110 students like non-fiction reading. Gender differences and their relationship with reading preferences were also studied and found that men really liked non-fiction reading while women preferred realistic fiction. However, girls will read more books and magazines and they have a greater tendency to read longer

The final question is about what reading topics students are interested in. Of the 14 choices offered, students can choose more than 1 reading that they are interested in. Student choices can be seen in the following Figure 1.

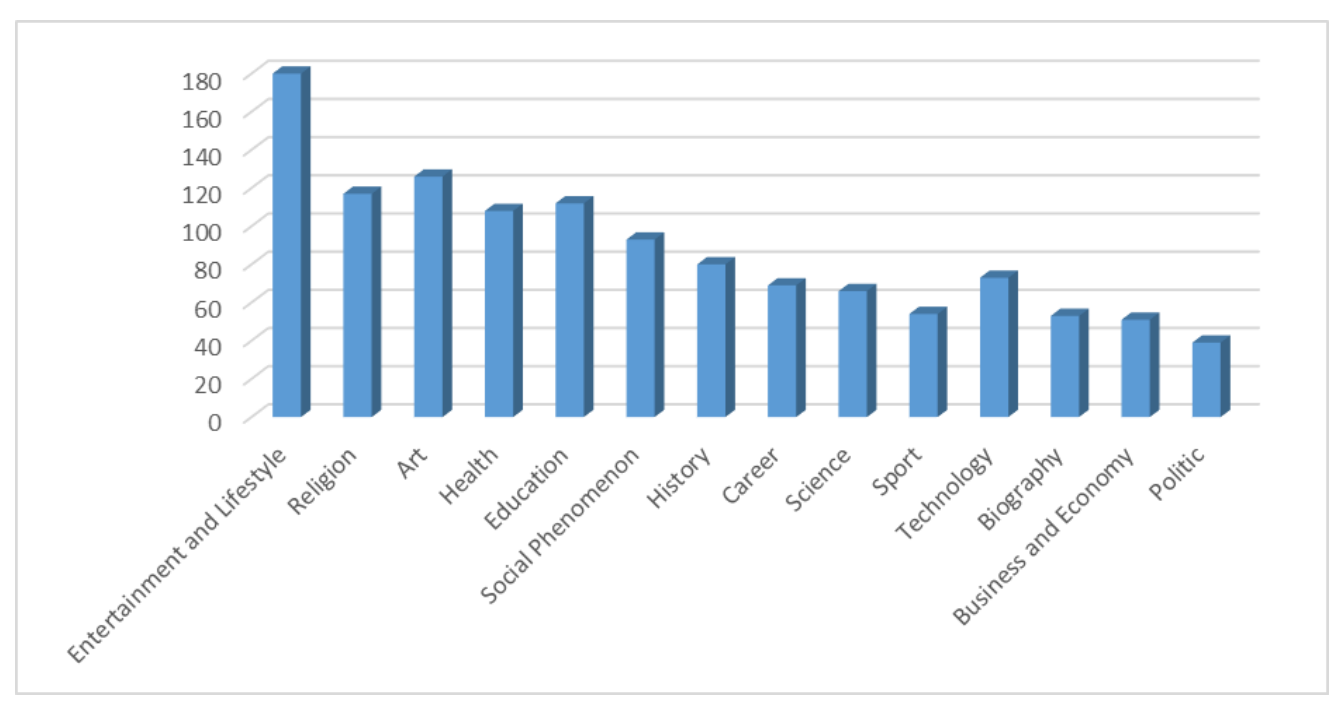

Figure 1. Preferred reading topics 
Of the 14 choices offered, students are also given what topic topics they like most and which they dislike most. Student responses can be seen in the following Figure 2.

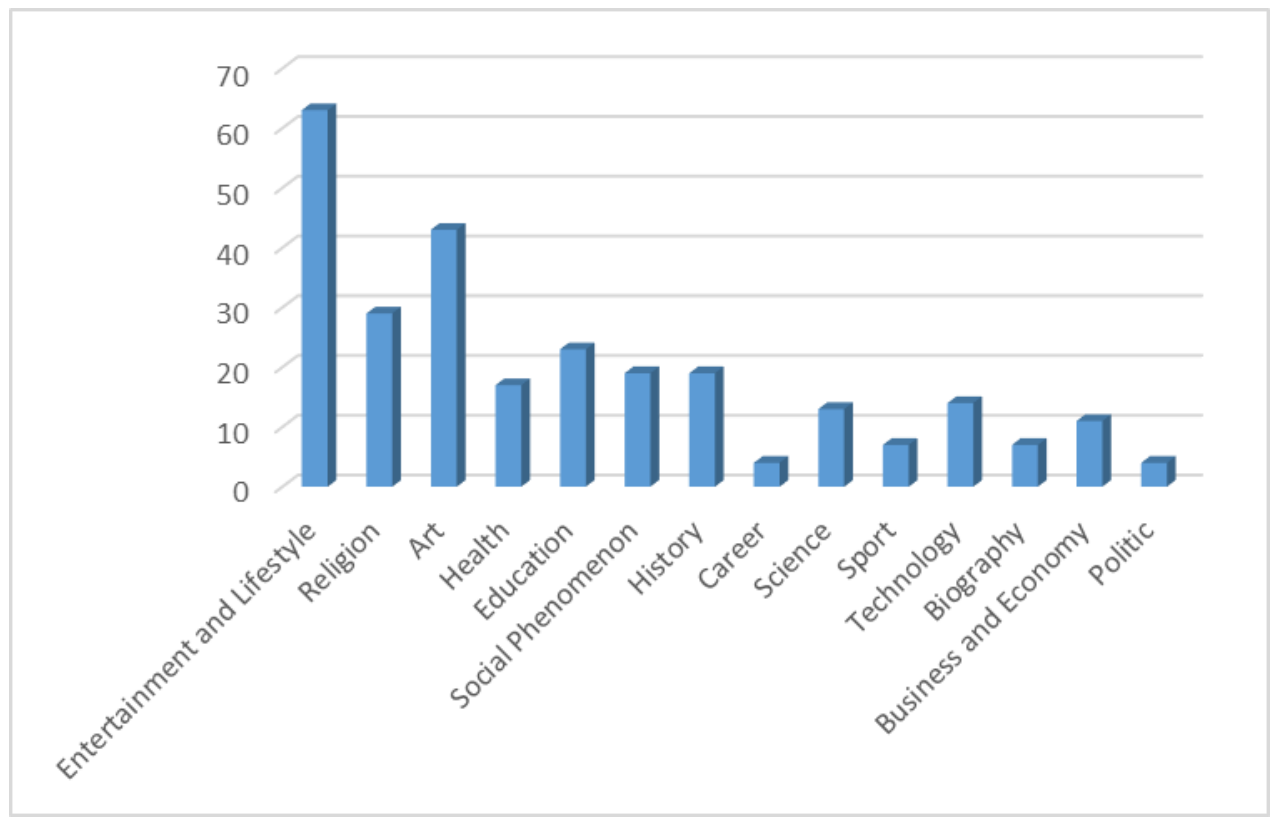

Figure 2. The most preferred reading topic

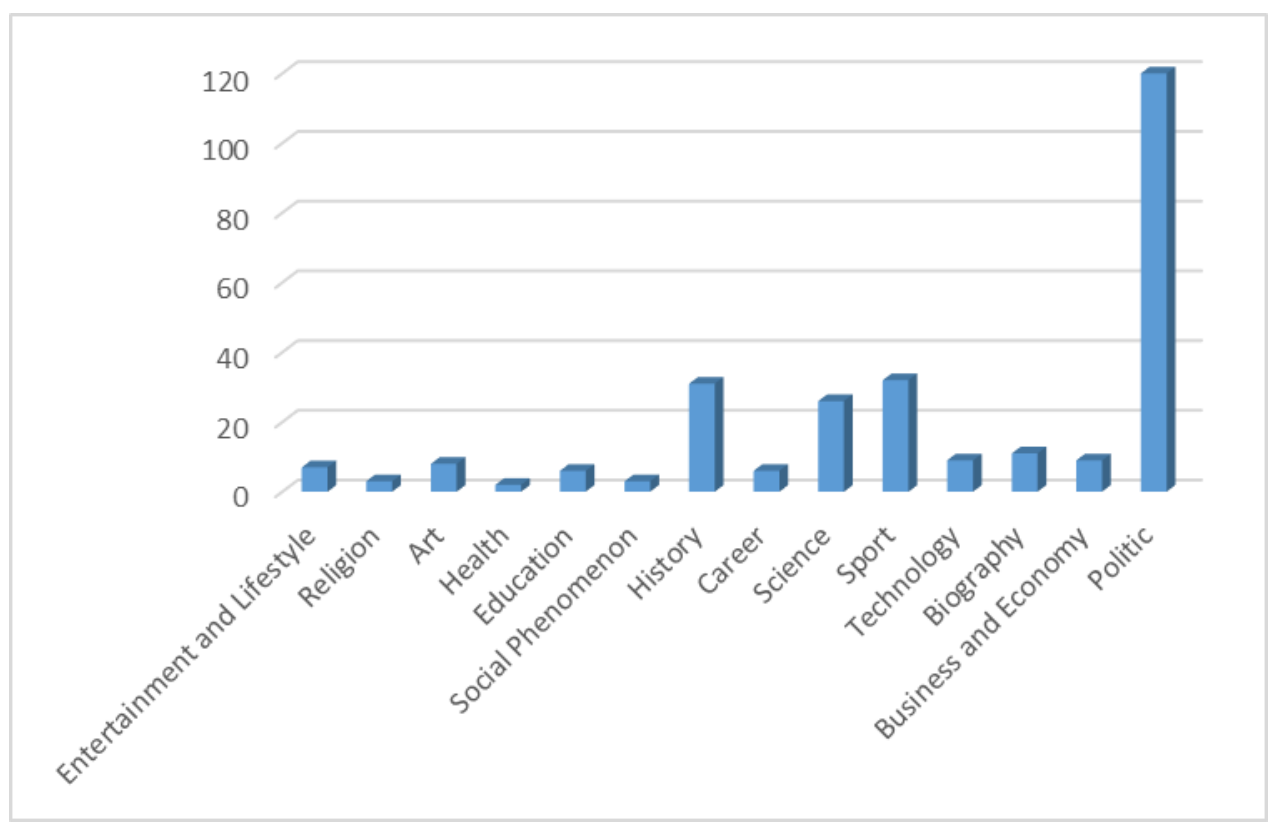

Figure 3. The most disliked reading topic

students like most, whereas politics is the topic most disliked by students.

From the Figure 3 above it can be seen that 


\section{DisCUSSION}

Based on the findings, it revealed that students of English Language teaching from all three universities in Jember has several attitudes toward reading activities. They mostly did not like reading activities in the classroom. For further reasons, the difficulties of material given become their prior obstacle of reading activities in the classroom. Related to the given material in the class, they did not always feel please with the text or reading material given by the lecturer. The reason behind it mostly because the material is too difficult and did not catch their interest. All this conditions then make the students limit their reading habit. Most of the students stated that they rarely doing the reading activity outside classroom. It also affect their reading collection that limited only on textbooks for classroom needs, and it is more about as an obligation not as their needs and interest of collecting it.

Related to the findings, quality of reading material become an important thing in reading activity. The lecturers should take a serious concern of material levels of difficulty before giving it to the students. Other important point about material quality is whether the material interests the students or not. Being interested to the material is very important to make students engage to the reading activities and follow all the instructions given.

An interesting reading will be a good starter for students to be fully bound to the overall content of the lesson. Conversely, when a reading is not interesting, while the reading is the main ingredient in a discussion of learning, or the source of learning activities, the chances of students not to pay attention to the overall content of the lesson will be even greater. By "giving someone an unattractive reading only kills their interest in reading. Providing reading that does not suit their reading preferences does not only affect the disinterest in reading material but the overall content of the lesson.

Lecturers decision about reading material in the classroom is particularly important because it is directly associated with student outcomes (Hairrell et al., 2011). Giving students reading materials, which consider the level of difficulties and students' preference, may help to improve the reading outcomes. The choices teachers make with regard to what is read in class thus have an enormous impact on the success of their students; teachers must therefore address the reading needs and interests the students.

Answering research question about students reading preference, based on the finding above, this study found that students of English Language Teaching in Jember prefer fiction than nonfiction text. They mostly love to read texts about entertainment and life style, arts, religious, education and historical text and really avoid political and sport theme for reading.

It has become a common observation that one's reading interest tends to vary from individual to individual. Preferences can be based on gender, age, background of their social environment, etc. Some people may be interested in reading romantic stories, while others are interested in historical events and geographical places including the wonders of the world. Likewise, some people may want to introduce themselves from scientific truths about nature, and some may feel attracted to religious principles.

One of the findings also shows that respondents spend more of their reading time on sources in the form of lecture books and literature books. The implication of this data is that students on that age tend to be able to focus their reading preferences on academic matters as an access to science. Thus, it can be concluded that when children prefer to read story books, cartoons, comics, popular magazines, and sports even though these books are rarely available in libraries, whereas in adults will tend to read reading that gives pleasure as well as life values such as articles, textbooks, literature books and newspapers. When children tend to be very eager to read more for practical life, then adults will be more interested in things that are individual development

Having identified the various reading preferences of students especially their interest and preference can be a solution of bored reading classroom. Lecturers can explain that reading extensively leads not only to gains in reading proficiency but also to overall gains in language learning. Teachers can reassure students that a general understanding of what they read is appropriate for most reading purposes is relevant for their course of study. Students here maybe responding well and better with a guide as well as solution to make them read in English, to have the knowledge as well as wisdom to converse and apply the language effectively.

Many literature highlights the importance of letting students choose certain texts to be studied in class, researched, or used in a test. Students also appreciate reading periods during which they are free to read what they like (Bozack, 2011). Many teachers allow their students to choose their books or texts. Giordano (2011) and Meyer (2010) 
reported that various reading activities regularly take place in the form of workshops, where the students are asked to choose books that interest them and that correspond to their specific needs during predetermined study periods and according to a prearranged system established by the teacher. Both of these authors emphasize that the book collection must be varied to include books that appeal to the reading preferences of each student (Giordano, 2011; Meyer, 2010).

Providing reading materials which support students reading preferences can be conducted in several ways. To find the informative text about entertainment and life style, religious and education theme, teacher may use encyclopedias, newspapers, and magazines, be both preserved and encouraged in class. The fact that art texts were ranked as the second most preferred reading material, teacher may use a judicious use of poetry and can be combined with other types of text to ensure variety, as well as to help students maintain a positive attitude toward their reading abilities and remain motivated in this regard.

Based on the finding that have been shown about their enjoyment of fictional texts, lecturers may use narrative reading material that contain more adventures or science-fiction content, or that fall into the category of thrillers or crime novels (Moeller, 2011). Other implication of this study is how the reading activity in the classroom should be connected to the universities or outside library. According to the literature, to improve their reading skills, students must have access to a library. In a study on teaching practices, Al-Barakat and Bataineh (2011) found that the fact of having a library exploration in the classroom has a positive influence on the level of interest and reading achievement, as does the universities library or public library. A solid professional collaboration between teachers and librarians appears to be another significant factor, as it enables students to fully exercise their knowledge in terms of reading skills (Roux, 2008). Lecturers should thus strongly encourage library use during class hours and invite their students to visit their neighborhood library to seek out new documentary sources for their school assignments, or simply to find books and other reading material suited to their interests.

In other studies, highly promising results have been obtained by using discussion forums, where the topics concerned both at-home and inclass reading activities, as well as the Internet to have students read directly on the computer or laptop rather than by conventional means. In other words, today's educators should look a way to integrate new technologies within their teaching practices pertaining to literacy. This way of teaching can be happened in the universities level which all the learning process mostly use computer or laptop, and also as students are both very open to the presence of different media in the classroom setting (Jenkins, 2009).

All of the data above is a very good consideration for solving the problem of students' low reading interest in class. Identifying reading preferences can have implications for the selection of teaching materials, the provision of teaching materials and the type of reading activities in the classroom. One of them is by choosing reading material only on the choices that are usually preferred by students. Knowing the students 'reading preferences becomes very necessary for the adaptation of all learning activities so that they can provide reading material that is in accordance with the students' reading preferences. So that students are expected to be able to increase their reading motivation.

\section{CONCLUSION}

The findings of this study indicate that students of the English Language Teaching program in Jember do not always like the reading texts given in their classrooms. The reason given is that the text does not suit student interest; the text is too difficult, and so on. In addition, from the findings, students have reading preferences concerning topics of lifestyle, health, education, arts and religion and greatly avoid reading topics related to politics and history.

From these findings, this study recommends that lecturers should be more sensitive to respecting their children's reading interests and giving them reading material based on their reading interest and preferences. The author of textbooks used in classroom also should develop their books based on topics that students like and must take responsibility for creating works that students want to read on. Librarians and lecturers must also play their part in developing reading habits by helping students to access to the reading material that suits their preferences.

\section{REFERENCES}

Ary, D., Jacobs, L.C. \& Razavieh, A. (1976). Pengantar Penelitian Pendidikan. Terjemahan oleh Arief Furchan. 1982. Surabaya: Usaha nasional 
Arikunto, S. (1998). Prosedur Penelitian. Jakarta: Rinneka Cipta

Jawa Pos. (22 April 2008). Wanita Kelas Bawah Lebih Mandiri, hlm. 3

Kansil, C.L. (2002). Orientasi Baru Penyelenggaraan Pendidikan Program Profesional dalam Memenuhi Kebutuhan Dunia Idustri. Transpor, XX (4): 54-5 (4): 57-61
Kumaidi. (2005). Pengukuran Bekal Awal Belajar dan Pengembangan Tesnya. Jurnal Ilmu Pendidikan. Jilid 5, No. 4,

Waseso, M.G. (2001). Isi dan Format Jurnal IImiah. Makalah disajikan dalam Seminar Lokakarya Penulisan artikel dan Pengelolaan jurnal Ilmiah, Universitas Lambung mangkurat, 9-11Agustus. 